(c) American Dairy Science Association, 2005.

\title{
Factors of Variation Influencing Bulk Tank Somatic Cell Count in Dairy Sheep
}

\author{
C. Gonzalo, ${ }^{1}$ J. A. Carriedo, ${ }^{1}$ M. A. Blanco, ${ }^{2}$ E. Beneitez, ${ }^{2}$ M. T. Juárez, ${ }^{2}$ \\ L. F. De La Fuente, ${ }^{1}$ and F. San Primitivo ${ }^{1}$ \\ ${ }^{1}$ Departamento de Producción Animal, Facultad de Veterinaria, \\ Universidad de León, 24071-León, Spain \\ ${ }^{2}$ Consorcio de Promoción del Ovino, 49630-Villalpando, Zamora, Spain
}

\section{ABSTRACT}

Between January and December 2002, a total of 21,685 records for bulk tank milk somatic cell count (BTSCC) were obtained from 309 dairy ewe herds belonging to the Sheep Improvement Consortium in Castilla-León, Spain. Based on the first statistical model, ANOVA detected significant effects of herd, breed, month within herd, dry therapy, type of milking, contagious agalactia, and installations within machine milking on logBTSCC. A second statistical model was used on herds with machine milking to study the effect of the vacuum level and pulsation rate on BTSCC. Herd and month within herd were important variation factors as they explained 48.4 and $16.1 \%$ of the variance in BTSCC. Variability in logBTSCC among breeds ranged from 5.84 (Castellana) to 6.09 (Awassi and Spanish Assaf). Implementing dry-ewe therapy (5.91) significantly reduced $\operatorname{logBTSCC}$ compared with when it was not implemented (6.10). Hand milking elicited greater $\operatorname{logBTSCC}$ (6.07) than machine milking (5.94). Machine milking of ewes in milking parlors (logBTSCC: 5.88 to 5.94) was associated with better udder health than was the use of bucket-milking machines (6.04). Reduced vacuum levels and elevated pulsation rate during machine milking optimized BTSCC. In all cases, clinical outbreaks of contagious agalactia increased BTSCC. As a result, dry therapy was proposed as the main tool to reduce BTSCC. Optimization of milking-machine standards and parlor systems also improved udder health in dairy sheep.

(Key words: bulk tank milk, somatic cell count, mastitis, milking)

Abbreviation key: BTSCC = bulk tank somatic cell count.

Received July 13, 2004.

Accepted November 24, 2004.

Corresponding author: C. Gonzalo; e-mail: dp2cga@unileon.es.

\section{INTRODUCTION}

In recent years several studies have focused on SCC and subclinical mastitis in dairy ewes. Subclinical infections caused by coagulase-negative staphylococci and other mammary pathogens elicit elevated SCC (Pengov, 2001; Ariznabarreta et al., 2002), cause severe damage to udder tissue (Burriel, 1997), and result in important losses of milk yield and composition (Gonzalo et al., 2002; Leitner et al., 2004) in dairy ewes. Other studies have revealed predictive values of SCC and its efficacy in diagnosing the infection (Marco, 1994; GonzálezRodríguez et al., 1995). Additional research has led to the development of strategies for mastitis control in dairy ewes based on antibiotic dry therapy (Marco, 1994; Gonzalo et al., 2004) and optimizing technical characteristics of milking machines (Peris et al., 2003a, b). Other variables with an important effect on ewe milk SCC were breed and flock (Gonzalo et al., 1994; González-Rodríguez et al., 1995), the sampling month (El-Saied et al., 1998), and clinical outbreaks of contagious agalactia (Bergonier et al., 1996).

Bulk tank SCC (BTSCC) is the first and principal tool used by technicians and farmers to evaluate udder health in flocks. However, no known studies exist that empirically investigate the effect of some recommended mastitis control practices on BTSCC under field conditions in dairy ewes. These BTSCC are affected by a number of sources of variation, and an attempt should be made to identify them and assess their implications in mastitis control or milk payment schemes. The European Union has yet to regulate BTSCC values in ewe milk used for dairy products sold in its region. Studies need to be carried out to identify the main sources of BTSCC variations in the primary dairy sheep areas of the European Union.

The purpose of this paper was to study BTSCC factors in mastitis control, particularly type of milking (hand or machine), characteristics of machine milking systems, dry therapy practices, and clinical outbreaks of contagious agalactia. In addition, other variables such as herd, breed, and month also were studied. 


\section{MATERIALS AND METHODS}

Between January 1 and December 31, 2002, 21,685 records of BTSCC were obtained from 309 dairy ewe herds (breeds: 238 Spanish Assaf, 12 Awassi, 41 Churra, and 18 Castellana) belonging to the Sheep Improvement Consortium of Castilla-León, Spain. Average herd size was 350 to 400 ewes, which was representative of the Castilla-León region. In most of the herds, lambing is concentrated in the autumn and spring. Each herd is generally divided into 2 lots, the lambing periods of which alternate every 4 to 6 mo in the herd. Some herds undergo a reproductive intensification to achieve 3 lambings every 2 yr, whereas in others, ewes have only 1 lambing per year. In addition, estrus is synchronized in some herds, but not in others, or only during certain times of the year, and this practice is not consistent within herds. Consequently, lambing periods are different among herds.

Sheep Improvement Consortium herds were enrolled in the Analysis Service of the Dairy Interprofessional Laboratory of Castilla-León (LILCyL). An average of 6 monthly samplings of bulk tank milk for SCC were carried out in each flock. The mean number of repeated records per flock throughout the year was 67 . All samples were preserved with azidiol and SCC was determined by the Fossomatic method (A/S N Foss Electric, Hillerød, Denmark).

The information recorded by the Sheep Improvement Consortium veterinary service included the following BTSCC factors: herd, breed, sampling month, dry therapy practice, milking type (hand or machine), and type of installations used for machine milking (buckets and milking parlors: looped milkline, dead-ended milkline, midlevel, and low-level systems). Antibiotic dry ewe therapy was given under veterinary supervision. In herds where dry therapy was implemented, all ewes were treated during dry period (complete dry therapy). In $15 \%$ of the herds, dry therapy was carried out in such a way that it only affected part of the year because of different lambing periods within herds. Farmers using dry therapy received the necessary veterinary advice and improved some aspects of milking hygiene and management (milking routines and postmilking teat disinfection) in the subsequent lactation.

Clinical outbreaks of contagious agalactia were reported and Mycoplasma agalactiae was isolated in bulk tank milk by microbiological laboratories. Once the clinical outbreak was produced in a herd, it was identified as positive for the time necessary for treatment, vaccination $(<15 \mathrm{~d}$ after outbreak), and revaccination (20 to $30 \mathrm{~d}$ after the first vaccination). During the rest of the year, it was classified as negative.
The technical characteristics of the milking machine were obtained from testing of milking machines carried out by the Sheep Improvement Consortium veterinary service. The following traits were studied: 1) vacuum level (average vacuum measured at the long milk tube with no milk flow); 2) vacuum effective reserve per unit measured at milking vacuum level (L/min free air); 3) pulsation rate (cycles per min); and 4) pulsation ratio (sum of the durations of the increasing vacuum phase and the maximum vacuum phase divided by the duration of the complete pulsation cycle in the pulsation chamber vacuum, expressed as a percentage).

\section{Statistical Analyses}

Statistical analyses were carried out for BTSCC records using 2 mixed models in which the herd within breed and the month within herd were included as random factors. The aim of the first model was to study BTSCC factors, whereas that of the second was to study the covariables of the milking machine.

The first analysis was done with 21,685 BTSCC records from 309 herds. A mixed model was used, in which herd and month within herd were random and the remaining effects were fixed. The PROC MIXED procedure (SAS Institute, 1992) was followed, according to the method below:

$$
\begin{aligned}
\mathrm{Y}_{\mathrm{ijk} k m n o r}= & \mu+\mathrm{B}_{\mathrm{i}}+\mathrm{H}_{\mathrm{j}(\mathrm{i})}+\mathrm{T}_{\mathrm{k}}+\mathrm{D}_{\mathrm{l}}+\mathrm{M}_{\mathrm{m}(\mathrm{ij})} \\
& +\mathrm{A}_{\mathrm{n}}+\mathrm{I}_{\mathrm{o}(\mathrm{k})}+\mathrm{e}_{\mathrm{ijk} l m n o r}
\end{aligned}
$$

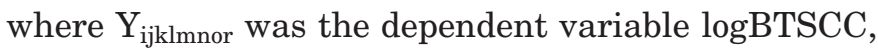
$B_{i}$ was the fixed effect of breed, $H_{j(i)}$ was the random effect of herd nested within breed, $\mathrm{T}_{\mathrm{k}}$ was the fixed effect of type of milking, $D_{1}$ was the fixed effect of dry therapy, $M_{m(i j)}$ was the random effect of month within herd, $A_{n}$ was the fixed effect of outbreak of contagious agalactia, $I_{o(k)}$ was the fixed effect of installation type nested within type of milking, and $\mathrm{e}_{\mathrm{ijk} \text { kmor }}$ was the random residual effect. The breed effect was divided into 4 levels: Spanish Assaf, Awassi, Churra, and Castellana. Type of milking effect was divided into 2 levels: hand and machine milking. Dry therapy was divided into 2 levels depending on whether it was carried out in each flock during the previous drying-off or not. In $15 \%$ of herds, this practice covered a part of year only. The contagious agalactia effect was divided into 2 levels: presence or absence of a clinical outbreak of $M$. agalactiae in bulk tank milk. Finally, the type of installation within machine milking was divided into 3 levels: bucket, parlor with looped milkline, and parlor with dead-ended milkline. In addition to this statistical analysis, the data also were analyzed classifying the milking 
Table 1. Tests of significance for fixed effects of factors affecting bulk tank SCC based on a mixed model analysis.

\begin{tabular}{lrc}
\hline Variation factor & $\mathrm{df}$ & \multicolumn{1}{c}{$F$} \\
\hline Breed & 3 & $8.83^{* * *}$ \\
Type of milking & 1 & $12.04^{* * * *}$ \\
Dry therapy & 1 & $113.09^{* * *}$ \\
Contagious agalactia & 1 & $23.72^{* * *}$ \\
Installation $^{\text {Herd within breed }}{ }^{1}$ & 2 & $2.70^{*}$ \\
Month within herd $^{2}$ & $\ldots$ & $\ldots$ \\
Total $^{2}$ & $\ldots$ & $\ldots$ \\
\hline
\end{tabular}

$* P<0.05$.

$* * * P<0.001$

${ }^{1}$ Levels of random factor herd: 309 .

${ }^{2}$ Levels of random factor month within herd: 3708 .

${ }^{1,2}$ Random factors absorbed in the model.

installation as bucket, midlevel, and low-level milking systems, using the same mathematical model.

Estimation of variance components was made for random factors of the model using the VARCOMP procedure of SAS according to REML methodology (SAS Institute, 1992). Percentages of variance explained by herd and month within herd were calculated by dividing the corresponding components of variance by the total variance. Considering repeated observations within herd, repeatability of BTSCC for herd was defined as the ratio of herd variance to the sum of the residual, month within herd, and herd variances.

To study the effect of the milking machine variables on logBTSCC, a second statistical analysis was carried out on the 17,234 SCC observations from 234 herds with machine milking. The mixed model used for this analysis was:

$$
\begin{aligned}
\mathrm{Y}_{\mathrm{ijlmnr}}= & \mu+\mathrm{B}_{\mathrm{i}}+\mathrm{H}_{\mathrm{j}(\mathrm{i})}+\mathrm{D}_{\mathrm{l}}+\mathrm{M}_{\mathrm{m}(\mathrm{ij})}+\mathrm{A}_{\mathrm{n}}+\mathrm{b}_{1} \mathrm{x}_{1 \mathrm{ij}} \\
& +\mathrm{b}_{2} \mathrm{x}_{2 \mathrm{ij}}+\mathrm{b}_{3} \mathrm{x}_{3 \mathrm{ij}}+\mathrm{b}_{4} \mathrm{x}_{4 \mathrm{ij}}+\mathrm{e}_{\mathrm{ijl} \mathrm{mnr}}
\end{aligned}
$$

where $b_{1}, b_{2}, b_{3}$, and $b_{4}$ were the slopes of regressions corresponding to the covariables, vacuum level, pulsation rate, effective reserve per unit, and pulsation ratio. Effects $\mathrm{H}_{\mathrm{j}(\mathrm{i})}$ and $\mathrm{M}_{\mathrm{m}(\mathrm{ij})}$ were random, and the remaining ones were fixed. In this mixed model, the PROC MIXED procedure of SAS (SAS Institute, 1992) was also used.

In both procedures used in the statistical analyses, the random factors were absorbed in the analysis and only the significance of the fixed effects is shown. Least squares means and test of significance were obtained for the fixed effects.

\section{RESULTS AND DISCUSSION}

Mean of $\operatorname{logBTSCC}$ was $5.95 \pm 0.002$ (geometric mean: $888 \times 10^{3}$ cells $/ \mathrm{mL}$ ). Table 1 shows the results from the mixed-model ANOVA of factors affecting BTSCC.
Table 2. Components of variance and variation explained by the random factors of the mixed model.

\begin{tabular}{lll}
\hline Random factors & Variance & $\begin{array}{l}\text { Variance } \\
\text { explained (\%) }\end{array}$ \\
\hline Herd within breed & 0.0396 & 48.4 \\
Month within herd & 0.0133 & 16.1 \\
Residual & 0.0154 & 18.6 \\
Total & 0.0806 & $\ldots$ \\
\hline
\end{tabular}

Breed, type of milking, machine-milking installation, dry therapy, and contagious agalactia contributed significantly to variation of BTSCC.

The components of variance for the random factors of the mixed model and the percentages of variance explained are shown in Table 2. Percentage of residual variance $(18.6 \%$ ) was relatively small, showing the relative suitability of the mathematical model used to study BTSCC. Special reference should be made to the herd that accounted for $48.4 \%$ of the total variance, and was therefore, the most important source of variation in BTSCC. This would be due to differences in management and hygiene practice in herds, which would also bring about considerable differences in the prevalence of mammary infection and BTSCC. Month within herd was also a relevant factor of variation in BTSCC (16.1\% of total variance). This factor explains variation in prevalence of mammary infection throughout the year in each herd. In view of the reproductive handling features throughout the year in the herds of this study, the month factor could also explain, although only in part, differences in stage of lactation within herds, due to lambing concentration. Nevertheless, this aspect could be debatable according to reproductive specific features of each herd. On the other hand, month as a variation factor not within herd was of little importance $(2.5 \%$ of total variance), and therefore was not considered in the mathematical model.

LogBTSCC repeatability of the random herd factor corresponding to repeated observations of BTSCC within herd was relatively large (0.58), because of the high percentage of variance explained by this variation factor $(48.4 \%)$. This result was compatible with the importance of herd in other studies of SCC test-day records (Gonzalo et al., 1994; González-Rodríguez et al., 1995). Repeatability of herd depends, in part, on the number of repeated records for herd throughout the year. This number was relatively large (average $=67$ ) in the present study. High repeatability found for BTSCC indicated the suitability of the recording system for BTSCC established in herds in the Castilla-León region. In this respect, this type of BTSCC recording can be used for monitoring udder health in dairy ewe herds and as a criterion for milk payment schemes. 
Table 3. Least squares means of bulk tank somatic cell count resulting from mixed model analysis corresponding to type of milking and machine-milking installation effects.

\begin{tabular}{|c|c|c|c|c|c|}
\hline Milking & Installation & $\begin{array}{l}\operatorname{LogSCC}^{1} \\
(\mathrm{SE})^{3}\end{array}$ & $\begin{array}{l}\mathrm{SCC}^{2} \\
\left(\times 10^{3} / \mathrm{mL}\right)\end{array}$ & $\begin{array}{l}\operatorname{LogSCC}^{1} \\
(\mathrm{SE})^{3}\end{array}$ & $\begin{array}{l}\mathrm{SCC}^{2} \\
\left(\times 10^{3} / \mathrm{mL}\right)\end{array}$ \\
\hline \multirow[t]{2}{*}{ Hand } & & $\begin{array}{c}6.07^{\mathrm{a}} \\
(0.03)\end{array}$ & 1189 & \multirow[t]{2}{*}{$\begin{array}{c}6.07^{\mathrm{a}} \\
(0.03)\end{array}$} & \multirow[t]{2}{*}{1189} \\
\hline & Bucket & $\begin{array}{r}6.04^{\mathrm{a}} \\
(0.07)\end{array}$ & 1101 & & \\
\hline \multirow[t]{2}{*}{ Machine } & Looped milk line & $\begin{array}{c}5.88^{\mathrm{b}} \\
(0.03)\end{array}$ & 760 & \multirow[t]{2}{*}{$\begin{array}{c}5.94^{\mathrm{b}} \\
(0.03)\end{array}$} & \multirow[t]{2}{*}{881} \\
\hline & Dead-ended milk line & $\begin{array}{c}5.91^{\mathrm{b}} \\
(0.03)\end{array}$ & 817 & & \\
\hline
\end{tabular}

\footnotetext{
${ }^{\mathrm{a}, \mathrm{b}}$ Means within column having different superscript letters differ $(P<0.05)$.

${ }^{1}$ Least squares means.

${ }^{2}$ Geometric means.

${ }^{3}$ Standard error.
}

Breed had an important effect $(P<0.001)$ on BTSCC. The Castellana breed produced the smallest BTSCC values (logBTSCC: 5.84 and a geometric mean of BTSCC: $692 \times 10^{3}$ cells $/ \mathrm{mL}$ ) and smallest milk yield $($ mean $=56.2 \mathrm{~L} /$ ewe per year $)$. Greater resistance to mastitis was demonstrated by Dario and Bufano (1991) in less-productive breeds compared with breeds that are more productive. This fact would imply a greater incidence of intramammary infections in the most productive ewes than in the least productive ones. In this respect, in our study, the Spanish Assaf (6.09 and 1233 $\times 10^{3}$ cells $/ \mathrm{mL}$ ) and Awassi (6.09 and $1226 \times 10^{3}$ cells/ $\mathrm{mL}$ ) breeds had the greatest BTSCC and milk yields (179.0 and 234.5 L per year, respectively). Similar results were reported in an earlier study (GonzálezRodríguez et al., 1995) on the half-udder milk in the same region, in which the Castellana breed had fewer SCC than the Assaf breed.

Dry therapy was a very important factor in explaining the variation in BTSCC. When dry therapy was implemented, BTSCC (5.91 and $823 \times 10^{3}$ cells/ $\mathrm{mL})$ was less $(P<0.001)$ than when this practice was not used $\left(6.10\right.$ and $1273 \times 10^{3}$ cells $\left./ \mathrm{mL}\right)$. Dry therapy was generally associated with improved milking hygiene in subsequent lactations, so this practice was efficient in reducing prevalence of intramammary infec- tions and improving quality of milk. These results confirm those in other studies on dairy ewes (Marco, 1994; Gonzalo et al., 2004).

Clinical outbreaks of contagious agalactia increased $(P<0.001)$ BTSCC compared with its clinical absence $\left(6.06\right.$ and $1157 \times 10^{3}$ cells $/ \mathrm{mL}$ vs. 5.96 and $905 \times 10^{3}$ cells $/ \mathrm{mL}$ ). Increases in SCC were also described in ewes experimentally infected with $M$. agalactiae (Bergonier et al., 1996). This disease is a serious limitation to improving udder health and the milk hygiene. The implementation of programs for its eradication should be a prerequisite for optimizing SCC and mastitis control strategies.

For milking type (Table 3), machine milking (5.94 and $881 \times 10^{3}$ cells $/ \mathrm{mL}$; logBTSCC and geometric mean, respectively) elicited a lower $(P<0.05)$ BTSCC than hand milking (6.07 and $1189 \times 10^{3}$ cell $\mathrm{s} / \mathrm{mL}$ ), similar to results obtained by Gonzalo and Gaudioso (1983). These results reflect the inferior hygiene conditions of hand milking compared with machine milking, which makes it more difficult for farmers to reach milk quality standards as measured by BTSCC. Within machine milking (Table 3), the bucket system (6.04 and $1101 \times$ $10^{3}$ cell $\left.\mathrm{s} / \mathrm{mL}\right)$ produced greater $(P<0.05)$ BTSCC values than parlor systems with looped milkline (5.88 and 760 $\times 10^{3}$ cells $/ \mathrm{mL}$ ) and dead-ended milk line (5.91 and 817

Table 4. Summarized statistics of machine milking covariables.

\begin{tabular}{|c|c|c|c|c|c|c|}
\hline Covariable & Mean & $\mathrm{SD}^{1}$ & $\mathrm{CV}^{2}(\%)$ & $\begin{array}{l}\text { Minimum } \\
\text { value }\end{array}$ & $\begin{array}{l}\text { Maximum } \\
\text { value }\end{array}$ & $\begin{array}{l}\text { No. of } \\
\text { different } \\
\text { values }\end{array}$ \\
\hline Vacuum level $(\mathrm{kPa})$ & 36.2 & 2.43 & 6.7 & 31.5 & 49.0 & 79 \\
\hline Effective reserve per unit (L/min) & 122.2 & 35.1 & 28.7 & 35.0 & 259.0 & 110 \\
\hline Pulsation rate (cycles/min) & 149.9 & 22.8 & 15.2 & 62.0 & 180.0 & 46 \\
\hline Pulsation ratio (\%) & 56.5 & 3.2 & 5.8 & 37.0 & 65.0 & 18 \\
\hline
\end{tabular}

${ }^{1}$ Standard deviation.

${ }^{2}$ Coefficient of variation. 
Table 5. Regression estimates of vacuum level and pulsation rate on bulk tank SCC indicating their test of significance.

\begin{tabular}{lclll}
\hline Covariable & Slope $^{1}(\mathrm{~b})$ & $\mathrm{SE}$ & $F$ & $\begin{array}{l}\text { Coefficient of } \\
\text { correlation (r) }\end{array}$ \\
\hline Vacuum level & 0.0131 & 0.0059 & $4.79^{*}$ & 0.24 \\
Pulsation rate & -0.0012 & 0.0006 & $3.85^{*}$ & -0.18 \\
\hline
\end{tabular}

$* P<0.05$.

${ }^{1}$ Parameters in the mixed model.

$\times 10^{3}$ cells $/ \mathrm{mL}$ ). When milking cows, it is generally recognized that looped milklines have advantages in providing greater effective capacity and more stable vacuum (Akam and Spencer, 1992). In contrast, differences in BTSCC found in parlors with looped milklines vs. dead-ended milkline (Table 3 ) were not significant $(P$ $>0.05$ ), although numerically, values were less for parlors with looped milklines. No significant differences in BTSCC were detected between low-level (5.88 and 763 $\times 10^{3}$ cells $/ \mathrm{mL}$ ) and mid-level (5.94 and $867 \times 10^{3}$ cells/ $\mathrm{mL})$ milking systems, although a difference $(P<0.05)$ in BTSCC was detected between bucket and these parlor systems. Elevated BTSCC for the bucket system may have occurred because the bucket used for sheep is usually adapted from those used for goats or cows, without having improved the milking conditions for this system in sheep. In addition, bucket-milking systems are not used in milking parlors in which conditions are more suitable for hygiene milking.

Finally, in previous statistical analyses, the significance of the milking $\times$ dry therapy interaction was studied, because this interaction may have some biological significance. However, this interaction was not significant and was therefore excluded from the final mathematical model.

Table 4 summarizes the effects of machine-milking covariables. Mean values ( \pm SE) for vacuum level, effective reserve per unit, rate of pulsation, and pulsation ratio were $36.2 \pm 0.02 \mathrm{kPa}, 122 \pm 0.26 \mathrm{~L} / \mathrm{min}$ free air, $149.9 \pm 0.17$ cycles per min, and $56.5 \pm 0.02 \%$. Coefficients of variation were moderately small for the pulsation ratio and vacuum level (5.8 and 6.7\%), but large for the effective reserve and pulsation rate (28.7 and $15.2 \%)$. This variability, together with the elevated number of different values found for these variables indicated that they could not be grouped together in a few classes and were therefore considered as covariables. Parameters $b_{1}$ and $b_{2}$ in the model were significant for the vacuum level and rate of pulsation, respectively, and estimates of regression for these variables on $\operatorname{logBTSCC}$ are shown in Table 5. The correlation coefficients between these variables and $\operatorname{logBTSCC}$ were $r=0.24$ for vacuum level and $r=-0.18$ for pulsation rate. The previous results disagree with those of
Peris et al. (2003a, b) in short term studies on dairy ewes. In contrast, other studies (Fernández et al., 1999) detected greater SCC in ewes milked at 42 vs. $36 \mathrm{kPa}$ and lower SCC in ewes milked at 180 vs. 120 cycles per min, which is confirmed by our results. Further, Rønningen and Lunder (1999) reported a statistical association between BTSCC and vacuum level and pulsation rate in dairy goats. Moreover, for the vacuum reserve per unit and pulsation ratio covariables, coefficients of regression $b_{3}$ and $b_{4}$ of the model were not statistically significant and therefore had no effect on BTSCC.

\section{CONCLUSIONS}

Herd, breed, month within herd, dry therapy, type of milking, contagious agalactia, and installation within type of milking were important factors influencing BTSCC in dairy sheep. The large repeatability of BTSCC identified for the herd factor in this study showed that the recording system used was ideal for this variable. The large amount of variation explained by herd and month within herd showed important variations in the prevalence of IMI among herds and within herds throughout the year. The BTSCC can therefore be used for monitoring udder health in dairy ewe herds and as a basis for milk payment schemes. The elevated BTSCC recorded indicates that incorporation of better hygiene practices would improve herd mammary health. Dry therapy practices and milking in parlor systems were associated with small BTSCC. More pulsations (180 cycles/min) and low vacuum levels (34 to $36 \mathrm{kPa}$ ) are equally as desirable for optimizing udder health in ewes. Specific programs for eradicating contagious agalactia should be implemented in enzootic areas.

\section{ACKNOWLEDGMENTS}

This paper was developed within the Plan Nacional I+D+i: project PETRI 95-0839.OP between the University of León (Spain) and the Sheep Improvement Consortium (Consorcio de Promoción del Ovino) in CastillaLeón, Spain.

\section{REFERENCES}

Akam, D. N., and S. B. Spencer. 1992. Design and operation of milking machine components. Pages 141-212 in Machine Milking and Lactation. A. J. Bramley, F. H. Dodd, G. A. Mein, and J. A. Bramley, ed. Insight Books, Huntington, VT.

Ariznabarreta, A., C. Gonzalo, and F. San Primitivo. 2002. Microbiological quality and somatic cell count of ewe milk with special reference to staphylococci. J. Dairy Sci. 85:1370-1375.

Bergonier, D., G. Gracianette, C. Andrieu, and X. Berthelot. 1996. Reproduction expérimentale de l'agalactie contagieuse de la brebis: évolution des comptages cellulaires individuels durant 
trois lactations consécutives. Pages 93-97 in Somatic Cells and Milk of Small Ruminants. EAAP Publ. No. 77. R. Rubino, ed. Wageningen Pers Publ., Wageningen, The Netherlands.

Burriel, A. R. 1997. Dynamics of intramammary infections in the sheep caused by coagulase-negative staphylococci and its influence on udder tissue and milk composition. Vet. Rec. 140:419-423.

Dario, C., and G. Bufano. 1991. Investigation of mastitis occurrence in purebred and crossbred ewes. Page 479 in Breeding for Disease Resistance in Farm Animals. J. B. Owen and R. F. E. Axford, ed. CAB Intl., Wallingford, UK.

El-Saied, U. M., J. A. Carriedo, and F. San Primitivo. 1998. Heritability of test day somatic cell counts and its relationship with milk yield and protein percentage in dairy ewes. J. Dairy Sci. 81:2956-2961.

Fernández, N., J. R. Díaz, C. Peris, M. Rodríguez, M. P. Molina, and A. Torres. 1999. Machine milking parameters for the Manchega sheep breed. Pages 233-238 in Milking and Milk Production of Dairy Sheep and Goats. EAAP Publ. No. 95. F. Barillet and N. P. Zervas, ed. Wageningen Pers, Wageningen, The Netherlands. González-Rodríguez, M. C., C. Gonzalo, F. San Primitivo, and P. Cármenes. 1995. Relationship between somatic cell count and intramammary infection of the half udder in dairy ewes. J. Dairy Sci. 78:2753-2759.

Gonzalo, C., A. Ariznabarreta, J. A. Carriedo, and F. San Primtivo. 2002. Mammary pathogens and their relationship with somatic cell count and milk yield losses in dairy ewes. J. Dairy Sci. 85:1460-1467.

Gonzalo, C., J. A. Carriedo, J. A. Baro, and F. San Primitivo. 1994. Factors influencing variation of test day milk yield, somatic cell count, fat and protein in dairy sheep. J. Dairy Sci. 77:1537-1542.
Gonzalo, C., and V. Gaudioso. 1983. Recuento celular en leche de oveja. Comparación entre ordeño mecánico y manual. Pages 268274 in Proc. 3rd Symp. Int. Machine Milking Small Ruminants, E. Ojeda, ed. Spanish committee, Valladolid, Spain.

Gonzalo, C., J. A. Tardáguila, L. F. De La Fuente, and F. San Primitivo. 2004. Effects of selective and complete dry therapy on prevalence of intramammary infection and on milk yield in the subsequent lactation in dairy ewes. J. Dairy Res. 71:33-38.

Leitner, G., M. Chaffer, A. Shamay, F. Shapiro, U. Merin, E. Ezra, A. Saran, and N. Silanikove. 2004. Changes in milk composition as affected by subclinical mastitis in sheep. J. Dairy Sci. 87:46-52.

Marco, J. C. 1994. Mastitis en la oveja Latxa: Epidemiología, diagnóstico y control. Ph.D. Thesis, Univ. Zaragoza, Spain.

Pengov, A. 2001. The role of coagulase-negative staphylococcus spp. and associated somatic cell counts in the ovine mammary gland. J. Dairy Sci. 84:572-574.

Peris, C., J. R. Díaz, S. Balasch, M. C. Beltrán, M. P. Molina, and N. Fernández. 2003a. Influence of vacuum level and overmilking on udder health and teat thickness changes in dairy ewes. J. Dairy Sci. 86:3891-3898.

Peris, C., J. R. Díaz, C. Segura, A. Martí, and N. Fernández. 2003b. Influence of pulsation rate on udder health and teat thickness changes in dairy ewes. J. Dairy Sci. 86:530-537.

Rønningen, O., and T. Lunder. 1999. Influence of milking machines on goat's milk quality in a Norwegian field study. Pages 507-512 in Milking and Milk Production of Dairy Sheep and Goats. EAAP Publ. No. 95, F. Barillet and N. P. Zervas, ed. Wageningen Pers. Publ., Wageningen, The Netherlands.

SAS Institute. 1992. SAS/STAT User's Guide, Version 6, 10th ed., SAS Institute Inc., Cary, NC. 